\title{
DISPERSAL, DISTRIBUTION AND ESTABLISHMENT OF ARBUSCULAR MYCORRHIZAL FUNGI: A REVIEW
}

\author{
Sara lucía Camargo-Ricalde \\ Depto. de Biología, Div. de Ciencias Biológicas y de la Salud, Universidad Autónoma Metropolitana- \\ Iztapalapa, Apdo. Postal 55-535, C.P. 09340, México, D.F. Tel. 58-04-46-90, y Depto. de Biología y \\ Conservación de la N aturaleza, U niversidad Agrícola de Noruega (N LH), P.O . Box 5014, N-1432, Aas, \\ Noruega, correo electrónico: slcr@xanum.uam.mx
}

\begin{abstract}
The aim of this paper is to review and assess scientific literature relevant to arbuscular mycorrhizal fungi (AMF) population dynamics: reproduction and dispersal mechanisms, and establishment and distribution in natural ecosystems. Arbuscular mycorrhizal fungi (AMF) are obligated root symbionts with an extraordinary capacity for growing, dispersing and surviving, but their life history is not well understood yet. Although there is information concerning AMF dispersal, distribution and establishment, some data are still ambiguous and contradictory. Arbuscular mycorrhizal fungi (AMF) life cycle responds to surrounding environment but even when they only reproduce asexually, their populations encompass a high genetic and functional diversity within ecosystems. Environmental disturbances create new habitats for AMF dispersal, which can take place by root to root contact, animal transport and erosion processes. These agents are the common dispersal mechanisms of AMF in nature. Distribution of AMF is influenced mainly by the environment and soil and plant communities, but the specific AMF-host plant association is thought to be secondary because the AMF must invade and colonize any host root for establishment. Thus, inoculum density, host and fungal genetic compatibility, edaphic factors and plant-microbial activity determine the formation of mycorrhizal infections.

Key words: arbuscular mycorrhizal fungi, dispersal, distribution, establishment.

Resumen. El objetivo de este trabajo es revisar y analizar la literatura científica relativa a la dinámica de poblaciones de los hongos micorrizógenos arbusculares (HMA): reproducción y mecanismos de dispersión, así como su establecimiento y distribución en los ecosistemas naturales. Los hongos micorrizógenos arbusculares (HMA) son simbiontes obligados de las raíces de las plantas y cuentan con una extraordinaria capacidad de crecimiento, dispersión y supervivencia; sin embargo, su historia de vida no se comprende todavía en su totalidad. Aunque se ha generado una gran cantidad de información relacionada con la dispersión, distribución y establecimiento de los HMA, hay una gran cantidad de ambigüedades y contradicciones. El ciclo de vida de los HMA responde al ambiente circundante; sin embargo, aunque su reproducción sea sólo asexual, presentan una alta diversidad genética y funcional dentro de los ecosistemas. Las perturbaciones en el ambiente crean nuevos hábitats para la dispersión de los HMA. Los mecanismos comunes de dispersión del inóculo en estos hongos son el contacto de raíz con raíz, el transporte animal y los procesos erosivos. La distribución de los HMA está influenciada principalmente por el ambiente, el suelo y las comunidades vegetales por lo que, en este caso, la asociación específica HMA-planta hospedera es secundaria. Para su establecimiento, los HMA deben invadir y colonizar cualquier raíz hospedante; por tanto, la densidad del inóculo, la compatibilidad genética entre el hospedero y el hongo, los factores edáficos y la actividad planta-microorganismos afectan la formación de infecciones micorrizógenas.
\end{abstract}

Palabras clave: hongos micorrizógenos arbusculares, dispersión, distribución, establecimiento.

A rbuscular mycorrhizal fungi (AMF) are associated with ca. $80 \%$ of living terrestrial plants (Pirozynski, 1981). They play a multifunctional role in ecosystems such as plant nutrient uptake facilitation and the improvement of plantsoil water relations for a wide range of species (Newsham $e t$ al., 1995a), affecting both their productivity and relative abundance, and ultimately influencing plant species diversity (Grime et al., 1987; Gange et al., 1990, 1993). Mycorrhizae are capable of influencing plant community structure within the ecosystems (Wilson and Hartnett, 1997, 1998; Van der Heijden et al., 1998). Moreover, mycorrhizal fungi have a high physiological diversity (Allen et al., 1995) due to a high genetic diversity (Sanders et al., 1996); consequently, mycorrhizal fungi have a high functional diversity within ecosystems (e.g. accumulation of toxic materials, decomposition of organic matter, protection from root pathogens, pro- 
duction of environmental biochemicals -antibiotics and enzymes-) (Miller, 1995; Zak and Visser, 1996).

In terms of nutrition, AMF require carbon from a host plant to survive. They can obtain carbon from the specialists living on limited plant species in particular habitats with long survival times (Warcup, 1981; Allen, 1991) to generalists found in swards or associated with early and later successional plant groups (Fitter, 1990; Titus and del Moral, 1998a, 1998b; Turner and Friese, 1998; Hartnett and Wilson, 1999).

Arbuscular mycorrhizal fungi (AMF) form a wide range of asexual spores or colonization structures (Zak and Visser, 1996), which allow them an extraordinary capacity for growing, dispersing and surviving (Allen, 1991); however, AMF life history is not yet well understood. Therefore, the aim of this paper is to review and assess scientific literature relevant to arbuscular mycorrhizal fungi (AMF) population dynamics: reproduction and dispersal mechanisms, and establishment and distribution in natural ecosystems. Mycorrhizae are important in both plant establishment and ecosystem restoration, and recently their importance in maintaining plant diversity and ecosystem functioning has been recognized.

\section{Mycorrhizal fungi life cycle}

As in many other fungi, the generalized life cycle of the mycorrhizal fungi (MF) (figure 1) responds in a highly plastic adaptation to its surrounding environment. An individual spore (sexual or asexual in the case of AMF), whether surviving a stress period or dispersing to a new habitat, will germinate producing a germ tube, which is a slender hypha initially having one growing tip. The hypha will expand and branch as long as conditions for growth are adequate to form a mycelium or hyphal network. This mycelium can be either haploid or diploid with each cell containing either one or more nuclei; it continues to expand until reaching an unfavorable habitat or contacting another compatible mycelium. Following this contact, anastomosis may occur between hyphae, followed by exchange of genetic material. The genetic material may either remain intact as separate nuclei (if the nuclei are the same, it is referred to as a homokaryon cell and if the nuclei are different, as a heterokaryon cell), or fuse to become diploid. Rarely, the fungus continues to grow with a 2 nucleus. More often, it undergoes sexual recombination to form new, recombined haploid nuclei. All four possibilities occur in mycorrhizal fungi, depending on the classification and genetic potential of each species (Allen, 1991; Zak and Visser, 1996).

Arbuscular mycorrhizal fungi (AMF) are thought to reproduce exclusively by asexual clamydospores and hyphal fragmentation, while ectomycorrhizal fungi (EMF) produce sexual spores (Allen et al., 1995). Due to hyphal fusion, gene turnover, and/or molecular drive, AMF individual clamydospores and hyphae may have hundreds to thousands of genetically different nuclei (heterokaryon), which can ex-

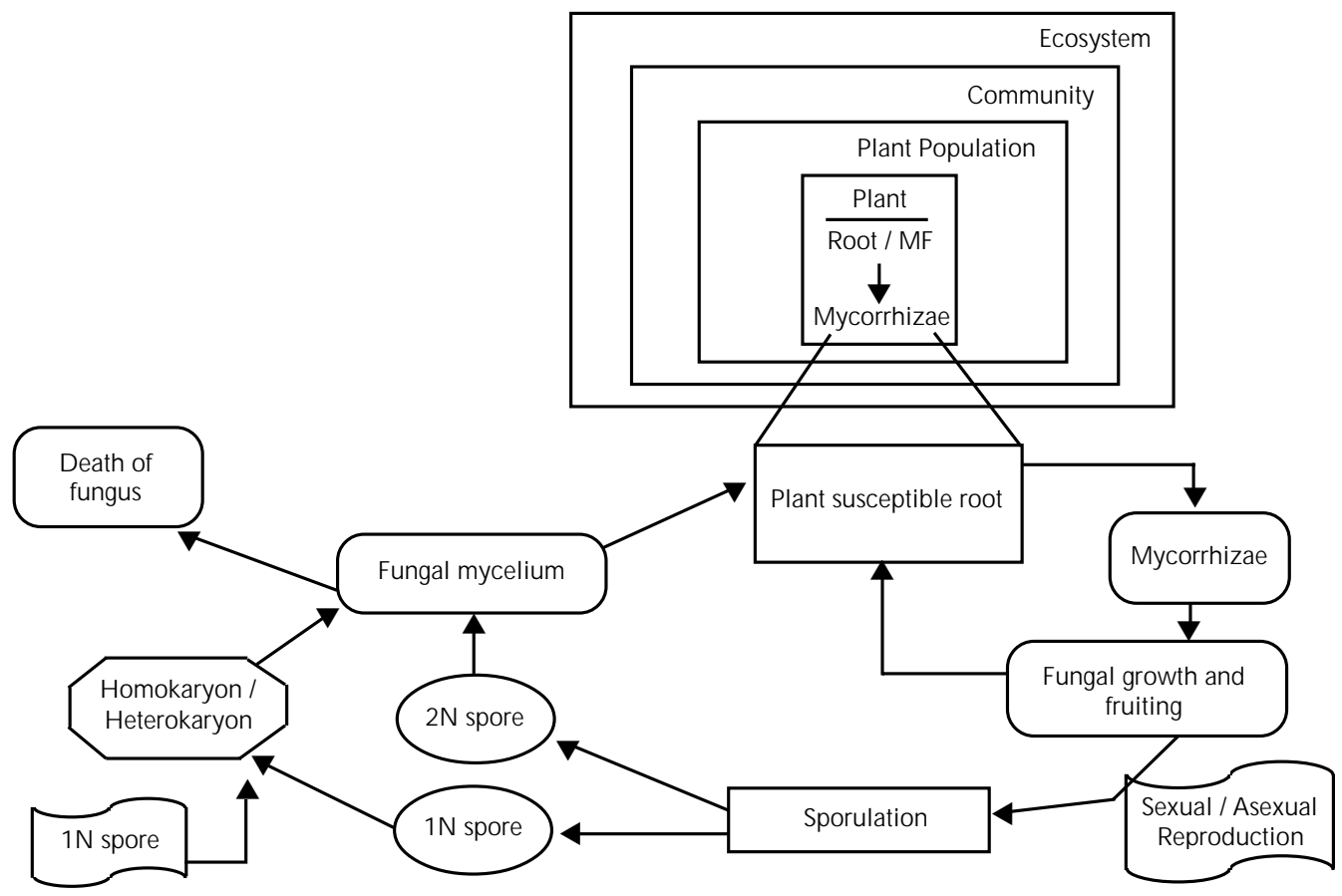

Figure 1. Generalized life cycle of mycorrhizal fungi (MF) (modified from Allen, 1991). 


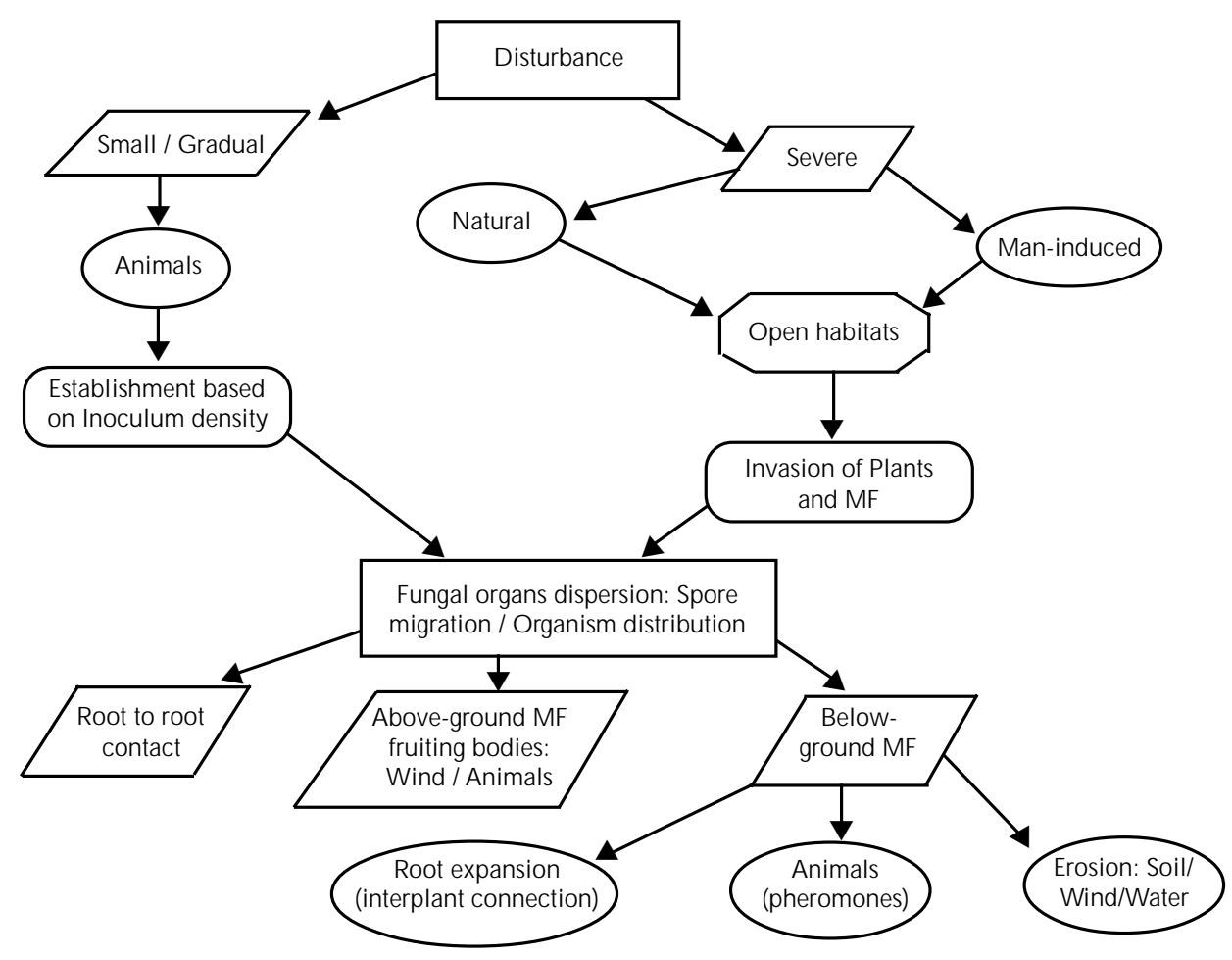

Figure 2. Dispersal mechanisms of mycorrhizal fungi (MF).

plain the high genetic diversity this kind of fungi possesses without any exchange of genetic material among individuals (Sanders et al., 1996). Consequently, a high functional diversity is found in AMF (Allen et al., 1995; Wildman, 1995; Streitwolf-Engel et al., 1997; Van der Heijden et al., 1998; Hartnett and Wilson, 1999).

A great part of the ecological role of an organism, and the strength and variety of population and community interactions are determined by growth form (Zak and Visser, 1996). Fungal mycelium presents a modular growth form, exhibiting a high plasticity in shape, size and reproductive potential, and the same genetic individual (genet) can simultaneously be exposed to different environments and selection pressures (Andrews, 1992; cited in Zak \& Visser, 1996). Modular growth provides fungi several specific attributes: indeterminate and iterative growth, maximum reproductive potential early in adult life, and an indefinite life span; fungi senescence and death may thus only be local, environmental effects on development are major, resources are obtained through growth across nutrient patches, and local disturbances are relatively unimportant (Zak and Visser, 1996). Fitness in fungi is therefore most readily defined in terms of population survival through time without enumerating offspring. This survival can take one of three forms: (1) the ability to retain a patch of soil through time, (2) the ability to tolerate stress conditions and reestablishment following the stress period, and (3) the ability to migrate and establish new colonies in new habitats (Allen, 1991).

It has been shown that MF can retain a patch of soil for long time periods; for example, some basidiomycetous mycorrhizal fungi form fairy rings that can last up to hundreds of years (Allen, 1991). Christensen (1989) registered the occurrence of many tropical fungi in temperate grassland soils, whose ancestors were originally deposited during the Pleistocene. In theory, mycelium and spores of many fungi have the capacity to survive for long time periods or maybe indefinitely (Allen, 1991).

Examples of AMF inoculum survivorship to stress conditions and their reestablishment through time are shown by several studies carried out to determine the role played by AMF and other factors (e.g. soil $\mathrm{pH}$ and texture) upon plant re-colonization after a disturbance process such as an early plant community succession (Nicolson, 1960; Allen and Allen, 1980; Gange et al., 1990, 1993) and Mount St. Helens eruption (Allen et al., 1984; Allen, 1987; Carpenter et al. 1987; Titus and del Moral, 1998a, 1998b).

\section{Dispersal of mycorrhizal fungi}

Disturbance. In order for mycorrhizal fungi to expand their range (figure 2), there must be a source of new habitats. Disturbances may represent the major source of these new habi- 
tats available to mycorrhizal fungi. Small or gradual disturbances such as those created by animals (e.g. soil removal mounds- while creating their burrows) still retain some existing inoculum, allowing those fungi a better chance for establishment based solely on inoculum density. Severe disturbances, natural (e.g. landslides, fire or volcano eruptions) or man-induced (e.g. mineral extraction or agriculture), create open habitats susceptible of invasion by new plants and mycorrhizal fungi (Allen, 1991). These disturbances may, or may not, lead to marked changes in the mycorrhizal formation (e.g. AM fungal species, AM fungal inoculum density, and AM fungal percentage of root colonization) (Abbot and Robson, 1991).

A well documented example of severe disturbance such as the eruption of Mount St. Helens, USA, in 1980, gave way to the study of several aspects concerning the mycorrhizal association: the process of AM fungal inoculum reestablishment (Allen et al., 1984; Allen, 1987), the role of the mycelia as part of the substrate for the colonization by non-vascular plants (Carpenter et al., 1987), and the relation between AMF presence/absence and the plant species composition in primary succession (Titus and del Moral, 1998a, 1998b). These studies concluded that in an early successional ecosystem, plants initially establish in distinct patches and that most of these plants are mycorrhizal. Dispersal, survival, and establishment (mycorrhizal colonization) of AM fungal association are thus important to the long term growth and survival of many plants (Allen and MacMahon, 1988), and of the AMF-plant association (Allen, 1991). Arbuscular mycorrhizal fungi (AMF) are thus one of the interacting factors influencing the competitive interaction among plant species that leads to the change of the plant species over successional time (Titus and del Moral, 1998a, 1998b). Allen et al. (1984) considered that the reconstruction of a given ecosystem depends, in part, on the ability of a particular fungus, such as the AMF or the EMF, to reach, survive at, and increase on a given site.

Spore density and dormancy. Spores of AMF are abundant in both nature and agricultural soils. However, results on spore density are related to the different methods employed (e.g. wet sieving and decanting method-Gerdemann and Nicolson (1963)-, including or not centrifugation, or different soil samples weight: $50 \mathrm{~g}$ or $100 \mathrm{~g}$ of dry soil). For instance, spore density ranged from 0 to 137 per $50 \mathrm{~g}$ of soil (Abbot and Robson, 1977), and from 2 to 1952 spores per $100 \mathrm{~g}$ of dry soil (Hayman and Stovold, 1979) in different Australian soil samples, and in a sand dune in USA, total spore density ranged from 0 to 677 per $100 \mathrm{~g}$ of sand (Sylvia, 1986). In the three studies, most of the samples contained at least two spore types. Hayman and Stovold (1979) demonstrated that there was no correlation between the size of an AM fungal spore population and the mycorrhizal infectivity, and that spore numbers were frequently lower in natural than in adjacent cultivated soils. In addition, Hayman (1982) showed that AM fungal spores can survive at least for one year in the field.

Furthermore, there are seasonal fluctuations in spore density, which varies greatly in relation to AM fungal and plant phenology; sometimes, both associated are phenologically synchronized. Sylvia (1986) and Gemma and Koske (1988) showed that both flowering and sporulation might occur almost simultaneously, and that newly-formed spores were dormant, apparently serving to maintain a high population of inoculum in the soil in the non-growing season of the hosts; for instance, dormancy in Gigaspora gigantea spores had two sequential limitations that inhibit their immediate germination: 2 to 9 week long period of dormancy followed by a temperature-imposed exogenous dormancy when temperature is below $15^{\circ} \mathrm{C}$ (Gemma and Koske, 1988).

Plant root to root contact and arbuscular mycorrhizal fungi (AMF) dispersal. Read et al. (1976) suggested that most AMF spread via root to root contact. Powell (1979) estimated that AMF could spread at rates of 6 to $43 \mathrm{~cm} /$ year by root expansion in a greenhouse experiment; while Warner and Mosse (1980) found that AM fungal hyphae expanded a few $\mathrm{dm} /$ year $(\mathrm{ca} .24 \mathrm{~cm})$ within sterile plots in the field. Natural spread of mycorrhizal fungi through plant root to root contact within the soil is thus slow (Powell, 1979) and greatly influenced by plant species presence (Warner and Mosse, 1980; Miller et al., 1989); most of the hyphae are located within 0.1 to 0.2 $\mathrm{cm}$ of the root surface ("nutrient depletion zone") having an effect similar to the one exercised by the root hairs (OwusuBennoah and Wild, 1979).

Ecologically, mycorrhizal growth leads to interconnections between plants, which favors the nutrient transfer among them. It is likely to be of great significance for survival of seedlings in circumstances where both, light and nutrients, are already extensively exploited by established plants. Nutrients move into the fungus from the source root and are then translocated through interconnecting hyphae to sink plants without entering into the soil solution (Whittingham and Read, 1982).

Mycorrhizal fungi (MF) dispersal by animals and erosion agents. Arbuscular mycorrhizal fungi (AMF) and some EMF have been observed to spread via small animals such as ants, grasshoppers, termites, wasps, birds, and rodents (McIlveen and Cole Jr., 1976; Maser et al., 1978; Allen et al., 1984; Allen, 1987; Warner et al., 1987; Koide and Mooney, 1987; Allen and MacMahon, 1988; Zoberi and Grace, 1990; Herrera et al., 1997), big mammals as ungulates, and bears (Cázares and Trappe, 1994), and via some erosion agents such as wind and water (Allen et al., 1984; Carpenter et al., 1987; Trappe, 1988).

Earthworms, termites and ants turn over large quantities of soil ( $c a .2$ to $5 \mathrm{~cm}$ of soil to the surface in a decade), playing an important role in both horizontal and vertical distribu- 
tion of AMF and EMF spores through dispersal of their casting material and soil removal (McIlveen and Cole Jr., 1976; Zoberi and Grace, 1990). Mycorrhizal inoculum has also been observed in gopher mounds in both serpentine grasslands (Koide and Mooney, 1987), and forest clearings (Allen et al., 1984; Allen and MacMahon, 1988), while communities of microfungi have been reported in rodent food stores (Herrera et al., 1997). Birds and mud dauber wasps are important in dispersal of mycorrhizal fungi spores in view of the distance and speed of dispersal, and not by the amount of inoculum they can disperse (McIlveen and Cole Jr., 1976).

On the other hand, most EMF, which fruit above ground, can also be dispersed across long distances if their spores are entrained in the upper air flows above the canopy; for example, the wind can move spores up to 2 $\mathrm{km}$ (Warner et al., 1987). Hypogeous fungi, as well as many forest floor mycorrhizal fungi, which produce brightly colored fruiting bodies, are eaten by squirrels and other small (Trappe and Maser, 1976; Maser et al., 1978) and big mammals (Cázares and Trappe, 1994), dispersing the spores through fecal pellets.

Thus, plant community re-colonization and/or permanence also depends upon dispersal of viable MF propagules, fungal inoculum establishment, presence of "adequate" plant propagules, and appropriate environmental conditions.

\section{Factors influencing arbuscular mycorrhizal fungi (AMF) distribution}

Arbuscular mycorrhizal fungi (AMF) are believed to be among the most abundant fungi in soil (Gerdemann and Nicolson, 1963). They are abundant in grasslands, savannas, scrub and open woodlands, rain forests, deserts and sand dunes; on a global scale, they are virtually ubiquitous (Hayman, 1982), and they differ greatly in their effects on plants, ranging from mutualistic to neutral to parasitic (Hayman, 1982; Fitter, 1991; Johnson et al., 1997). Though AMF are obligated root symbionts, very little about their population dynamics is known; however, some insights have been gained by studying the natural distributions of their spores (Johnson et al., 1992; Hartnett and Wilson, 1999).

Distribution, activity and survival of AMF have been shown to be influenced by several factors (table 1) such as soil fertility, soil moisture, soil compaction, soil depth, soil water saturation, $\mathrm{pH}$, topography, burning frequency, temperature, light intensity, altitude, latitude, plant susceptibility-phenology, AMF phenological variations and environmental disturbance, as well as by the physical movement of the water within the soil, and by the earthworms and the soil microfauna activities (Hayman, 1982).

Distribution of AMF changes across a soil moisture-nutrient gradient (Anderson et al., 1984), soil pH can influence AMF infection, sporulation, and spore germination (Green et al., 1976; Porter et al., 1987a, b), and low levels of phos- phorus within the soil can regulate AMF spore germination and root colonization (Hetrick and Wilson, 1989).

Soil compaction can deplete AM fungal growth. Nadian et al. $(1997,1998)$ considered that the absence of any observable mycorrhizal growth response in highly compacted soil was attributed to the significant decrease in the oxygen $\left(\mathrm{O}_{2}\right)$ content of the soil atmosphere, change in soil pore size distribution, and probably to ethylene production from impeded roots or to any combination of these factors.

The analysis of the influence of soil depth on mycorrhizal performance shows certain controversy. Jakobsen and Nielsen (1983) found that the proportion of root length infected decreased in relation to soil depth $(>40 \mathrm{~cm})$ and that the susceptibility to infection was independent of host species, while Zajicek and Hetrick (1986) observed that the degree of colonization varied with plant species and soil depth, and suggested that the deep-rooted growth habit of certain plants (e.g. forbs) probably is a survival mechanism by which competition for water and nutrients with shallower-rooted and fast-growing plants (e.g. grasses) is avoided, since soil fertility generally decreases as soil depth increases. Another example is the woody legume Prosopis glandulosa that develops functional root symbiotic associations with nitrogen $\left(\mathrm{N}_{2}\right)$-fixing bacteria and AMF at depths greater than $4 \mathrm{~m}$, and population densities of both symbiotic organisms are substantially greater at depth than near the surface (Virginia et al., 1986).

In a marsh, Cooke et al. (1993) determined that the presence of infected roots at $42.5 \mathrm{~cm}$ depth and the lack of detectable oxygen at this depth suggested that sufficient oxygen transport occurs in host plants to sustain the growth of the AMF in the roots. Miller (2000) found that AMF colonization was strongly negatively correlated with water depth and concluded that flooding was partially but not totally inhibitory to AM fungal colonization, ratifying Søndergaard and Laegaard (1977), Koske et al. (1985), and Cooke et al. (1993) previous conclusions.

Other factors, such as topography and burning frequency, affect gradients of variation in AMF species. Nevertheless, much of the AMF species compositional gradients may be also an indirect consequence of topographic and fire effects on plant species distributions (Gibson and Hetrick, 1988).

Temperature can also influence AM fungal species richness distribution along a latitudinal (north-south) gradient, although temperature effects on the AMF communities may be separated into two components: a direct effect on the fungi and an indirect effect mediated through the host plant (Koske, 1987). Allen et al. (1995) found that AMF exhibited a latitudinal gradient of occurrence. There were three distinct communities of fungi within two sites indicating that AMF form their own specific community patterns regardless of the host plant.

Phenological variations occur in AM fungal populations, as well as in saprophytic and pathogenic fungi populations. 
Table 1. Factors influencing arbuscular mycorrhizal fungi (AMF) distribution

\begin{tabular}{llll}
\hline Source & Factor & Research Site & Effect \\
$\begin{array}{ll}\text { Anderson et al. } \\
(1984)\end{array}$ & $\begin{array}{l}\text { Soil fertility and } \\
\text { moisture }\end{array}$ & Tallgrass prairie & $\begin{array}{l}\text { AM fungal species richness was positively correlated with percentage soil } \\
\text { organic matter and negatively correlated with Ca, M g, and P content of } \\
\text { soil, while total spore number was positively correlated with } \mathrm{N} \text { and } \\
\text { organic matter content and negatively correlated with Ca, Mg and } \mathrm{P} \\
\text { content of soil. }\end{array}$ \\
\hline
\end{tabular}

Nadian et al. Soil compaction Greenhouse: pots

Total P uptake was significantly greater in mycorrhizal plants than in nomycorrhizal ones; the response was smaller as soil compaction was (1997, 1998) increased. Soil compaction to a bulk density $1.6 \mathrm{M} \mathrm{g} \mathrm{m}^{-3}$ had no effect on the percentage of root length colonized, but total root length colonized decreased as soil compaction was increased. Soil compaction, which increased bulk density from 1.20 to $1.75 \mathrm{Mg} \mathrm{m}^{-3}$, reduced $\mathrm{O}_{2}$ content of the soil atmosphere from 0.16 to $0.05 \mathrm{~m}^{3} \mathrm{~m}^{-3}$.

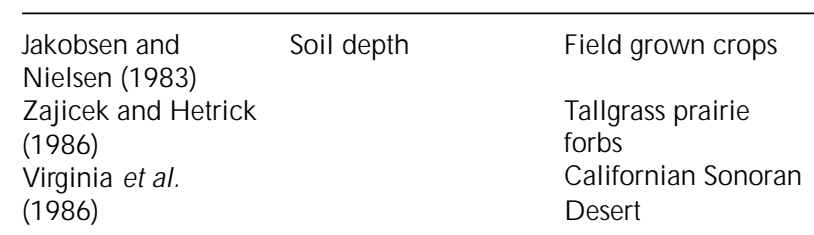

The proportion of root length infected decreased markedly below $40 \mathrm{~cm}$ soil depth; root density varied greatly between crops, whereas the absolute length of infected roots was similar. The degree of colonization varied with plant species and soil depth; spores of Glomus fasciculatum were found to a depth of $220 \mathrm{~cm}$. Prosopis glandulosa developed functional root symbiotic associations with $\mathrm{N}_{2}$-fixing nodules and AM F at depths greater than $4 \mathrm{~m}$ in moist soil above a seasonally stable water table.

\begin{tabular}{|c|c|c|c|}
\hline Cooke et al. (1993) & Soil $\mathrm{H}_{2} \mathrm{O}$ saturation & Salt marsh grasses & $\begin{array}{l}\text { Roots were colonized by AMF to a depth of } 42.5 \mathrm{~cm} \text {, but none arbuscule } \\
\text { was observed below } 37.5 \mathrm{~cm} \text {. }\end{array}$ \\
\hline Miller (2000) & & $\begin{array}{l}\text { Semi-aquatic grasses } \\
\text { along an hydrologic } \\
\text { gradient }\end{array}$ & $\begin{array}{l}\text { AM fungal colonization was strongly, negatively correlated with water } \\
\text { depth; colonization was lowest in plots that were consistently wet but } \\
\text { rose as some plots underwent seasonal drying; soils that were wet for }>1 \\
\text { year had the same ability to form mycorrhizas in bait plants as those that } \\
\text { had remained dry. }\end{array}$ \\
\hline
\end{tabular}

\begin{tabular}{|c|c|c|c|}
\hline $\begin{array}{l}\text { Green et al. (1976) } \\
\text { Porter et al. (1987a, } \\
\text { b) }\end{array}$ & Soil pH & $\begin{array}{l}\text { Greenhouse: pot } \\
\text { cultures } \\
\text { Greenhouse: pot } \\
\text { cultures }\end{array}$ & $\begin{array}{l}\text { AM F spores germination was influenced by } \mathrm{pH} \text { : Glomus mosseae } \\
\text { germinated best at } \mathrm{pH} 7 \text {, Gigaspora coralloidea at } \mathrm{pH} 5 \text {, and } \mathrm{G} \text {. } \\
\text { heterogama at } \mathrm{pH} 6 \text {. } \\
\mathrm{pH} \text { influenced the ability of infection, sporulation, and spore germination: } \\
\text { Acaulospora leavis was distributed in soil samples ranging from } \mathrm{pH} 4.5- \\
4.9 \text {, two species of Gigaspora from } \mathrm{pH} 4.5-6.4 \text { and three different strains } \\
\text { of Glomus at } \mathrm{pH} 5.5-8.4 \text {. }\end{array}$ \\
\hline
\end{tabular}

\begin{tabular}{|c|c|c|c|}
\hline $\begin{array}{l}\text { Johnson et al. } \\
\text { (1992) } \\
\text { Sylvia et al. (1993) }\end{array}$ & $\begin{array}{l}\text { Diverse soil factors } \\
\text { (composition, } \\
\text { texture, structure, } \\
\text { nutrients, pH, etc.) } \\
\text { Diverse plant and } \\
\text { soil systems }\end{array}$ & $\begin{array}{l}\text { Plots of } \\
\text { monocultures of five } \\
\text { successional grass } \\
\text { species } \\
\text { Greenhouse and } \\
\text { growth chambers }\end{array}$ & $\begin{array}{l}\text { Even closely related hosts (five grasses) may cause divergence in AM } \\
\text { fungal communities on initially identical soils; fungal communities in the } \\
\text { sandy end of the soil gradient diverged predictably from the fungal } \\
\text { communities in the black soil end of the gradient. } \\
\text { AMF isolates exist which are effective in promoting plant growth over a } \\
\text { range of edaphic and host conditions. }\end{array}$ \\
\hline $\begin{array}{l}\text { Gibson and Hetrick } \\
\text { (1988) }\end{array}$ & $\begin{array}{l}\text { Topography and } \\
\text { burning frequency }\end{array}$ & $\begin{array}{l}\text { Plots in a tallgrass } \\
\text { prairie }\end{array}$ & $\begin{array}{l}\text { Gradients of variation in AMF species were related primarily to } \\
\text { topography and burning frequency and secondarily to original plot } \\
\text { position with experimental plot rows. }\end{array}$ \\
\hline Koske (1987) & Temperature & $\begin{array}{l}\text { Plots on a latitudinal } \\
\text { gradient along a } \\
\text { barrier dunes }\end{array}$ & $\begin{array}{l}\text { Average AM fungal species richness was positively correlated with } \\
\text { distance south along the gradient and with temperature parameters. }\end{array}$ \\
\hline Allen et al. (1995) & $\begin{array}{l}\text { Latitudinal gradient } \\
\text { of occurrence }\end{array}$ & $\begin{array}{l}\text { Plots in the Mojave } \\
\text { Desert }\end{array}$ & $\begin{array}{l}\text { There were distinct northern, central and southern communities of fungi. } \\
\text { Glomus aggregatum and G. fasciculatum occurred throughout the range } \\
\text { of sagebrush, G. deserticola was restricted to the central and southern } \\
\text { portions of its range, Scutellospora calospora occurred along the western } \\
\text { and northern portions of the range, and G. mosseae was southern and } \\
\text { central in distribution. AM F form their own specific community patterns } \\
\text { regardless of the host plant (Artemisia tridentata). }\end{array}$ \\
\hline
\end{tabular}


Arbuscular mycorrhizal fungal communities present differences in relative density, spore production and differential activities, correlated to the environment (e.g. rainy season $v s$. dry season), to the host plant species (e.g. host specificity) and to other fungal species (e.g. competitive interactions) (Dhillion and Anderson, 1993; Gange et al., 1993; Abbot and Gazey, 1994; Miller, 1995; Merryweather and Fitter, 1998a, 1998b; Titus and del Moral, 1998a, 1998b; Turner and Friese, 1998). The competitive ability of AMF can be affected by many factors, such as the host plant species, particular environmental conditions, AMF phenology, inoculum frequency and its differential incubation time, the spatial distribution of the interacting propagules (Koske, 1981; Wilson, 1984), and the specific AMF genetic traits (Sanders et al., 1996), as well as by the presence of ectomycorrhizae (Moyersoen et al., 1998). These findings illustrate the importance of selecting an efficient AM fungal strain, native or introduced, to inoculate into disturbed soils for ecological restoration or for agricultural purposes (Lambert et al., 1980; Porter et al., 1987b; Stahl et al., 1988).

The hypothesis that environment, soil, and plant communities influence more AMF distribution than the specific AMF-plant association, is partially supported by these studies. However, other studies have demonstrated that there is a functional relationship between the species of AMF selected by a particular plant species (Hayman, 1982; Carey et al., 1992; Johnson et al., 1992; Dhillion and Anderson, 1993; Hartnett et al., 1993; Sylvia et al., 1993; West et al., 1993a, b; Allen et al., 1995; Clapp et al., 1995; Miller, 1995; Newsham et al., 1995b; Titus and del Moral, 1998a, b). Particular AMF species are able to provoke specific effects on plant performance (Stahl et al., 1990; Streitwolf-Engel et al.,
1997; Van der Heijden et al., 1998; Hartnett and Wilson, 1999). For instance, AMF influence the clonal growth of two species of Prunella (Lamiaceae), P. vulgaris and P. grandiflora (Streitwolf-Engel et al., 1997). Therefore, AM fungal species and/or communities influence plant communities through either stabilizing or destabilizing feedback mechanisms (Van der Heijden et al., 1998).

\section{Establishment of mycorrhizal fungi}

E. Stahl (1900, Jahrbücher für Wissenschafliche Botanik 34:539-668, cited in Allen, 1991) divided plants into nonmycotrophic, facultatively mycotrophic and obligately mycotrophic in relation to plant families; however, it would be unwise to assume that a plant would be non-mycorrhizal or mycorrhizal because it belongs to a particular family (Newman and Reddell, 1987), since it has been established that mycotrophy or non-mycotrophy is an expression of ecological adaptation (Bellgard, 1991). It was believed that within a community, the lack of mycorrhizae was a characteristic of early successional habitats (Nicolson, 1960; Pendleton and Smith, 1983). Nowadays, it is known that ruderal plant species, which frequently colonize disturbed sites, are often facultative mycotrophs (Francis and Read, 1994); Corkidi and Rincón (1997) observed the mycotrophy of seven plant species distributed in different successional stages in a sand dune ecosystem along the Gulf of Mexico shore; however, it looks like early successional annuals are predominantly nonmycotrophic.

For their establishment, AMF must invade and colonize roots (figure 3), either if AMF arise from a localized contact or from a dispersed inoculum. Allen (1991) considered that

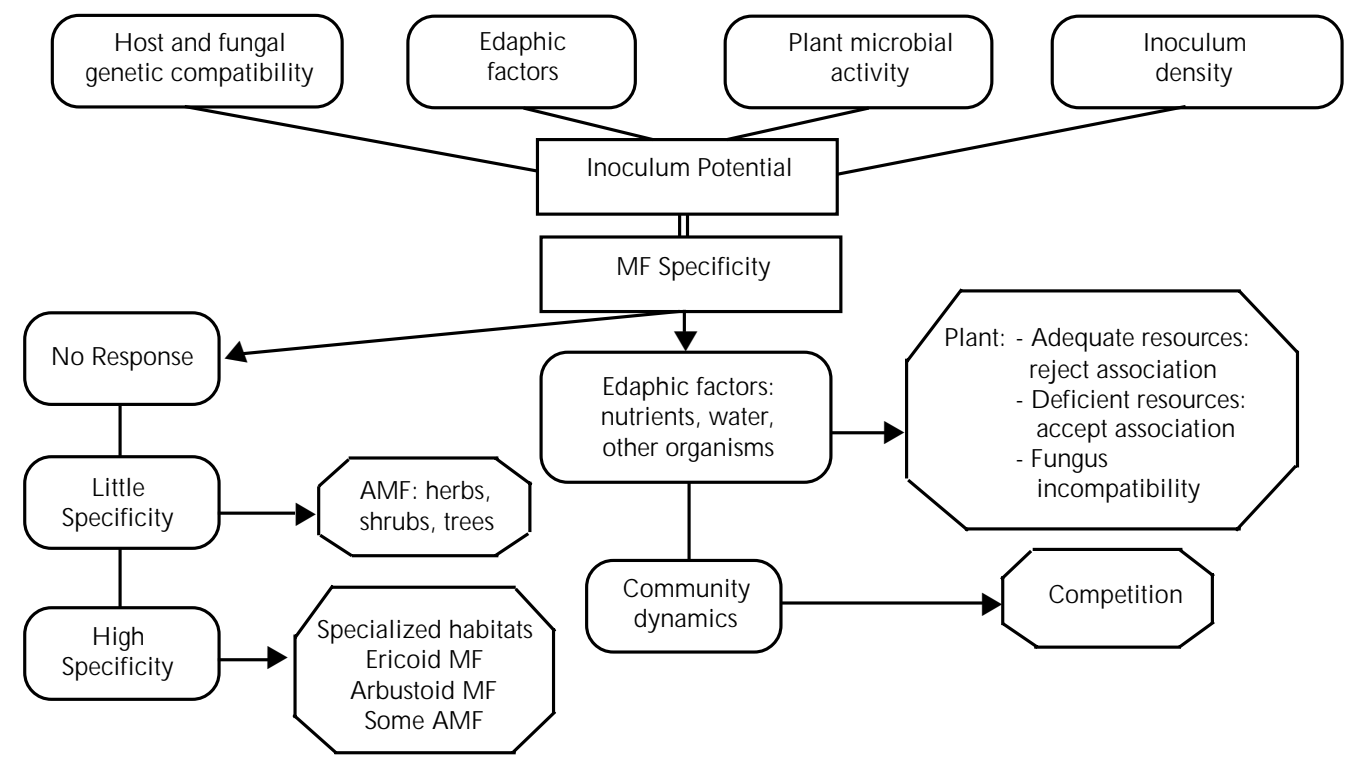

Figure 3. Factors affecting mycorrhizal fungi (MF) establishment. 
inoculum density, host and fungal genetic compatibility, edaphic factors, and plant-microbial activity influence the formation of the mycorrhizal association.

According to Morton (1990), once genes for specialized processes interacting with both plants and AMF were widely distributed among the symbionts, only those characters responsible for co-adaptational changes in mycorrhizal phenotypes continued to evolve in clonal subunits. These processes resulted thus in coadaptation between arbuscular clones and those hosts having compatible "symbiosis genes". Recently, it has been strongly suggested that the degree of compatibility or "specificity" between AMF and host plant might rely on specific biochemical regulatory processes initiated in the host as a result of the attempts of colonization by the fungus; the induction of compatibility or incompatibility reactions must be thus determined by the particular host-fungus combination (Douds et al., 1998). Furthermore, Hayman (1982), Fitter (1991), and Johnson et al. (1997) described the AMFhost plant association as a mutualism-parasitism continuum related to the cost-benefit received by the plant. Mycorrhizal associations are beneficial (mutualistic) to plants when net costs are less than net benefits (e.g. improved access to limiting soil resources), and detrimental (parasitic) when costs exceed benefits (e.g. reduction of root growth).

In the case of edaphic factors (table 1), they affect the ability of both plant and AMF to disperse and survive. High available nutrient levels and saturated soils often reduced mycorrhizal associations (Powell, 1980; Anderson et al., 1984). Allen (1991) formulated two assumptions in order to explain this process: (1) if the plant has access to all necessary resources, the association will not form or will be strongly reduced as the fungus then becomes a carbon drain, and (2) the fungus will invade any root encountered. Both hypotheses assume that the plant is the regulating agent.

The activity of neighboring plants is also known to affect mycorrhizal formation. Competition between plants determines the available resources. If a high density exists, resources will be lower and, just as low soil nutrient concentrations can stimulate colonization, increasing competition can result in resource depletion and increase AMF colonization (Allen and Allen, 1980; Grime et al., 1987; Gange et al., 1993; Van der Heijden et al., 1998; Hartnett and Wilson, 1999).

On the other hand, AMF do not colonize regions infected by endoparasitic nematodes, and nematodes rarely infect regions colonized by AMF; both organisms are often mutually exclusive, each reducing the population of the other (Ingham, 1988). Hence, antagonistic interactions take place between soil organisms and AMF, as well as predation on hyphae by nematodes and microarthropods (St. John and Coleman, 1982; Fitter, 1985).

The rate and intensity of spreading and colonization differs among AM fungal species, as well as the type of colonization structures (root length occupied by hyphae, arbuscules or vesicles) (Duke et al., 1994). It has been suggested that the type and rate of colonization of the different structures may be more important than the absolute amount of fungal biomass in the root, indicating that aspects of the AM fungus-plant relationship may be different in the same plant and/ or in different plant species through time in relation to the exploitation of temporary nutrient pulses or patches, and to phenological changes; it ratifies that several AM fungal species can be involved in a single association (Miller et al., 1989; Sanders and Fitter, 1992; Duke et al., 1994).

Mycorrhizal fungi have a wide range of specificity responses (Warcup, 1981; Molina and Trappe, 1982). Some, such as many species of Glomus, show almost no specificity within plant species capable of forming arbuscular mycorrhizae (AM) (Van der Heijden et al., 1998; Hartnett and Wilson, 1999). In some Australian orchid associations (Warcup, 1981), EM fungal specificity was highly variable: some associations were highly specific (e.g. Caladenia and Sebacina vermifera) and others were not. Allen (1991) pointed out that many ericoid mycorrhizal fungi can associate with a wide diversity of heathland shrubs, which tend to be highly stable through time; these shrubs do not form mycorrhizae with other plants; this ensures these fungi a host, despite changes in plant community.

Nevertheless, even if host-specific EMF are able to form ectomycorrhizas with a wider range of hosts, sexual reproduction via sporocarp production may still be mediated through specific host association (Molina and Trappe, 1982). On the other hand, many of the fungi that form arbuscular mycorrhizae show little specificity (Clapp et al., 1995). Arbuscular mycorrhizae (AM) can be formed on herbs as well as shrubs and trees (Allen, 1991).

However, other studies have shown that particular AM fungal species can be highly specific; in this case, AM fungal specificity is related to specialized habitats. For instance, Dhillion (1992) demonstrated that indigenous mycorrhizal fungal isolates showed considerable amount of host preference in a tall grass prairie (e.g. Glomus geosporum, Schizachyrium scoparium, and Andropogon gerardi), and Hartnett and Wilson (1999) concluded that there is a differential host species response to fungal specific colonization that can explain the dominance of $\mathrm{C}_{4}$ perennial grasses in a tallgrass prairie.

Finally, it is important to point out that both AMF and EMF often grow together in the same root (Bellgard, 1991). Both fungal groups are equally able to colonize the same niche, although competitive exclusion can take place; EMF synthesize enzymes that can inhibit AMF growth (Moyersoen et al., 1998).

\section{Final comments}

In part, the limited studies of the AM association as a function of both organisms is due to the different scales needed 
and the complexity of interactions between levels of organization within the system: AM fungal species-host plant. For a better understanding on the mechanisms and interactions related to AMF evolution and ecology through their life cycle, further research is needed (figure 4). For instance, research on mycorrhizae considers the effects of the association on the physiology or production of individual plants; the two mutualists are thus rarely studied as individual organisms which interact enhancing the survival of each other.

A recent approach to the arbuscular mycorrhizal association is focused on the importance of AMF in the ecological restoration of disturbed areas. For example, some studies carried out in the arid and semiarid regions of Mexico have shown that most of the established perennial plant species are mycorrhizal (Carrillo-García et al., 1999; CamargoRicalde et al., in press), and that AM fungal spores are important components of the resources islands created by dif- ferent shrubs and trees (e.g. Bursera fagaroides, Mimosa luisana) (Carrillo-García et al., 1999; Camargo-Ricalde and Dhillion, in press); however, AM fungal population dynamics remain not well understood.

Finally, to completely understand the AM fungal population dynamics, an integrative research including both, the above- and below-ground organisms interactions and environmental factors, is needed.

\section{Acknowledgements}

To Shivcharn S. Dhillion from the Agricultural University of Norway (NLH) for his support and the critical revision of this manuscript; to the Consejo Nacional de Ciencia y Tecnología (CONACyT, grant 112386), and to the Universidad Autónoma Metropolitana.

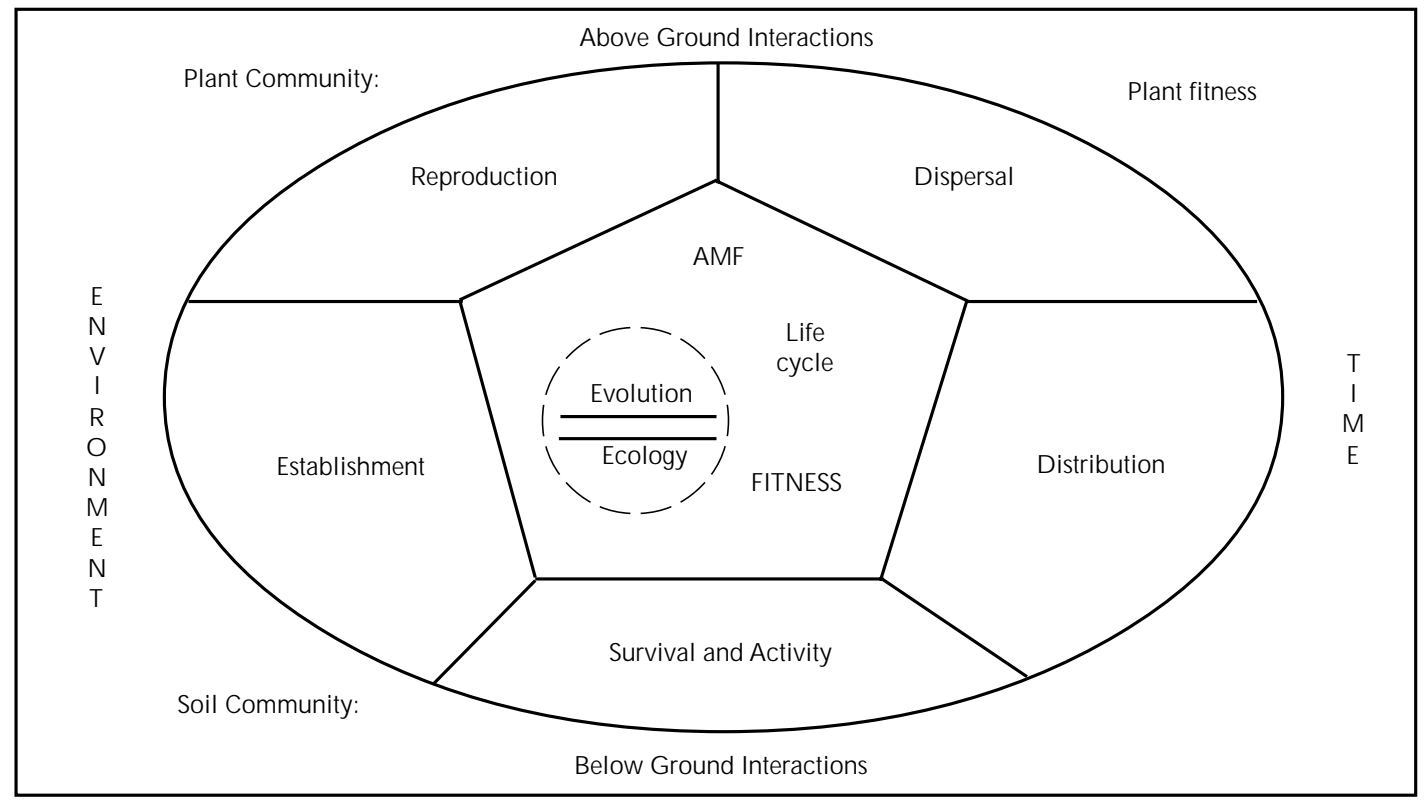

Figure 4. Arbuscular mycorrhizae fungi (AMF) evolution and ecology must be understood in terms of AMF contribution to both AMF and plant fitness. AMF life cycle responds to surrounding environment; thus, it expresses how these fungi have adapted to natural selection pressures through time. In ecological terms, AMF life cycle points out the factors and interactions involved in their reproduction (e.g. specific AM fungal species-host plant), dispersal (e.g. new habitats and root to root contact), distribution (e.g. environment, soil and plant community), and establishment (e.g. specificity, competition, mutualistic-parasitic continuum association).

\section{Literature Cited}

Abbot L.K. and Robson A.D. 1977. The distribution and abundance of vesicular arbuscular endophytes in some western Australian soils. Australian Journal of Botany 25:515-522.

Abbot L.K. and Robson A.D. 1991. Factors influencing the occurrence of vesicular-arbuscular mycorrhizas. Agriculture, Ecosystems and Environment 35:121-150.
Abbot L.K. and Gazey C. 1994. An ecological view of the formation of VA mycorrhizas. Plant and Soil 159:69-78.

Allen E.B. and Allen M.F. 1980. Natural re-establishment of vesicular-arbuscular mycorrhizae following stripmine reclamation in Wyoming. Journal of Applied Ecology 17:139-147.

Allen E.B., Allen M.F., Helm D.J., Trappe J.M., Molina R. and Rincón E. 1995. Patterns and regulation of mycorrhizal plant and fungal diversity. Plant and Soil 170:47-62. 
Allen M.F. 1987. Re-establishment of mycorrhizas on mount St. Helens: migration vectors. Transactions of the British Mycological Society 88:413-417.

Allen M.F. (Ed) 1991. The ecology of mycorrhizae. Cambridge University Press. New York.

Allen M.F., MacMahon J.A. and Andersen D.C. 1984. Reestablishment of endogonaceae on Mount St. Helens: survival of residuals. Mycologia 76:1031-1038.

Allen M.F. and MacMahon J.A. 1988. Direct VA mycorrhizal inoculation of colonizing plants by pocket gophers (Thomomys talpoides) on Mount St. Helens. Mycologia 80:754-756.

Anderson R.C., Liberta A.E. and Dickman L.A. 1984. Interaction of vascular plants and vesicular-arbuscular mycorrhizal fungi across a soil moisture-nutrient gradient. Oecologia 64:111-117.

Bellgard S.E. 1991. Mycorrhizal associations of plant species in Hawkesbury Sandstone vegetation. Autralian Journal of Botany 39:357-364.

Camargo-Ricalde S.L. and Dhillion S.S. In press. Endemic Mimosa species can serve as mycorrhizal "resource islands" within semiarid communities of the Tehuacán-Cuicatlán Valley, Mexico. Mycorrhiza (DOI 10.1007/s00572-002-0206-5; Published online: 16 October 2002).

Camargo-Ricalde S.L., Dhillion S.S. and Jiménez-González C. In press. Mycorrhizal perennials of the "matorral xerófilo" and the "selva baja caducifolia" communities in the semiarid Tehuacán-Cuicatlán Valley, Mexico. Mycorrhiza (DOI 10.1007/ s00572-002-0203-8; Published online: 19 October 2002).

Carey P.D., Fitter A.H. and Watkinson A.R. 1992. A field study using the fungicide benomyl to investigate the effect of mycorrhizal fungi on plant fitness. Oecologia 90:550-555.

Carpenter S.E., Trappe J.M. and Ammirati J. Jr. 1987. Observations of fungal succession in the Mount St. Helens devastation zone, 1980-1983. Canadian Journal of Botany 65:716-728.

Carrillo-García A., León de la Luz J.L., Bashan Y. and Bethlenfalvay G.J. 1999. Nurse plants, mycorrhizae, and plant establishment in a disturbed area of the Sonoran Desert. Restoration Ecology 7:321-335.

Cázares E. and Trappe J.M. 1994. Spore dispersal of ectomycorrhizal fungi on a glacier forefront by mammal mycophagy. Mycologia 86:507-510.

Christensen M. 1989. A view of fungal ecology. Mycologia 81:119.

Clapp J.P., Young J.P.W., Merryweather J.W. and Fitter A.H. 1995. Diversity of fungal symbionts in arbuscular mycorrhizas from a natural community. New Phytologist 130:259-265.

Cooke J.C., Butler R.H. and Madole G. 1993. Some observations on the vertical distribution of vesicular mycorrhizae in roots of salt marsh grasses growing in saturated soils. Mycologia 85:547550.

Corkidi L. and Rincón E. 1997. Arbuscular mycorrhizae in a tropical sand dune ecosystem on the Gulf of Mexico. II. Effects of arbuscular mycorrhizal fungi on the growth of species distributed in different early successional stages. Mycorrhiza 7:1723.

Dhillion S.S. 1992. Evidence for host-mycorrhizal preference in native grassland species. Mycological Research 96:359-362.

Dhillion S.S. and Anderson R.C. 1993. Seasonal dynamics of dominant species of arbuscular mycorrhizae in burned and unburned sand prairies. Canadian Journal of Botany 71:1625-1630.

Douds D.D. Jr., Galvez L., Bécard G. and Kapulnik Y. 1998. Regu- lation of arbuscular mycorrhizal development by plant host and fungus species in alfalfa. New Phytologist 138:27-35.

Duke S.E., Jackson R.B. and Caldwell M.M. 1994. Local reduction of mycorrhizal arbuscule frequency in enriched soil microsites. Canadian Journal of Botany 72:998-1001.

Fitter A.H. 1985. Functioning of vesicular-arbuscular mycorrhizas under field conditions. New Phytologist 99:257-265.

Fitter A.H. 1990. The role and ecological significance of vesiculararbuscular mycorrhizas in temperate ecosystems. Agriculture, Ecosystems and Environment 29:137-151.

Fitter A.H. 1991. Costs and benefits of mycorrhizas: implications for functioning under natural conditions. Experientia 47:350355.

Francis R. and Read D.J. 1994. The contributions of mycorrhizal fungi to the determination of plant community structure. Plant and Soil 159:11-25.

Gange A.C., Brown V.K. and Farmer L.M. 1990. A test of mycorrhizal benefit in an early successional plant community. New Phytologist 115:85-91.

Gange A.C., Brown V.K. and Sinclaire G.S. 1993. Vesiculararbuscular mycorrhizal fungi: a determinant of plant community structure in early succession. Functional Ecology 7:616622.

Gemma J.N. and Koske R.E. 1988. Seasonal variation in spore abundance and dormancy of Gigaspora gigantea and in mycorrhizal inoculum potential of a dune soil. Mycologia 80:211-216.

Gerdemann J.W. and Nicolson T.H. 1963. Spores of mycorrhizal Endogone species extracted from soil by wet sieving and decanting. Transactions of the British Mycological Society 46:235244.

Gibson D.J. and Hetrick B.A.D. 1988. Topographic and fire effects on the composition and abundance of VA-mycorrhizal fungi in tallgrass prairie. Mycologia 80:433-441.

Green N.E., Graham S.O. and Schenk N.C. 1976. The influence of $\mathrm{pH}$ on the germination of vesicular-arbuscular mycorrhizal spores. Mycologia 68:929-934.

Grime J.P., Mackey J.M.L., Hillier S.H. and Read D.J. 1987. Floristic diversity in a model system using experimental microcosms. Nature 328:420-422.

Hartnett D.C., Hetrick B.A.D., Wilson G.W.T. and Gibson D.J. 1993. Mycorrhizal influence on intra- and interspecific neighbor interactions among co-occurring prairie grasses. Journal of Ecology 81:787-795.

Hartnett D.C. and Wilson G.W.T. 1999. Mycorrhizae influence plant community structure and diversity in tallgrass prairie. Ecology 80:1187-1195.

Hayman D.S. and Stovold G.E. 1979. Spore populations and infectivity of vesicular arbuscular mycorrhizal fungi in New South Wales. Australian Journal of Botany 27:227-233.

Hayman D.S. 1982. Influence of soils and fertility on activity and survival of vesicular-arbuscular mycorrhizal fungi. Phytopathology 72:1119-1125.

Herrera J., Kramer C.L. and Reichman O.J. 1997. Patterns of fungal communities that inhabit rodent food stores: effect of substrate and infection time. Mycologia 89:846-857.

Hetrick B.A.D. and Wilson G.W.T. 1989. Suppression of mycorrhizal fungus spore germination in non-sterile soil: relationship to mycorrhizal growth response in big bluestem. Mycologia 81:382-390.

Ingham R.E. 1988. Interactions between nematodes and vesicular- 
arbuscular mycorrhizae. Agriculture, Ecosystems and Environment 24:169-182.

Jakobsen I. and Nielsen N.E. 1983. Vesicular-arbuscular mycorrhiza in field-grown crops. I. Mycorrhizal infection in cereals and peas at various times and soil depths. New Phytologist 93:401-413.

Johnson N.C, Tilman D. and Wedin D. 1992. Plant and soil controls on mycorrhizal fungal communities. Ecology 73:20342042.

Johnson N.C., Graham J.H. and Smith F.A. 1997. Functioning of mycorrhizal association along the mutualism-parasitism continuum. New Phytologist 135:575-585.

Koide R. and Mooney H.A. 1987. Spatial variation in inoculum potential of vesicular-arbuscular mycorrhizal fungi caused by formation of gopher mounds. New Phytologist 107:173-182.

Koske R.E. 1981. A preliminary study of interactions between species of vesicular-arbuscular fungi in a sand dune. Transactions of the British Mycological Society 76:411-416.

Koske R.E., Friese C.F., Olexia P.D. and Hauke R.L. 1985. Vesicular-arbuscular mycorrhizas in Equisetum. Transactions of the British Mycological Society 85:350-353.

Koske R.E. 1987. Distribution of VA mycorrhizal fungi along a latitudinal temperature gradient. Mycologia 79:55-68.

Lambert D.H., Cole H. Jr. and Baker D.E. 1980. Adaptation of vesicular-arbuscular mycorrhizae to edaphic factors. New Phytologist 85:513-520.

Maser C., Trappe J.M. and Nussbaum R.A. 1978. Fungal-small mammal interrelationships with emphasis on Oregon forests. Ecology 59:799-809.

McIlveen W.D. and Cole H. Jr. 1976. Spore dispersal of Endogonaceae by worms, ants, wasps, and birds. Canadian Journal of Botany 54:1486-1489.

Merryweather J. and Fitter A.H. 1998a. The arbuscular mycorrhizal fungi of Hyacinthoides non-scripta. I. Diversity of fungal taxa. New Phytologist 138:117-129.

Merryweather J. and Fitter A.H. 1998b. The arbuscular mycorrhizal fungi of Hyacinthoides non-scripta. II. Seasonal and spatial patterns of fungal populations. New Phytologist 138:131-142.

Miller D.D., Bodmer M. and Schüepp H. 1989. Spread of endomycorrhizal colonization and effects on growth of apple seedlings. New Phytologist 111:51-59.

Miller S.L. 1995. Functional diversity in fungi. Canadian Journal of Botany 73:S50-S57.

Miller S.P. 2000. Arbuscular mycorrhizal colonization of semiaquatic grasses along a wide hydrologic gradient. New Phytologist 145:145-155.

Molina R. and Trappe J.M. 1982. Lack of mycorrhizal specificity by the ericaceous hosts Arbutus menziesii and Arctostaphylos uva-ursi. New Phytologist 90:495-509.

Morton J.B. 1990. Species and clones of arbuscular mycorrhizal fungi (Glomales, Zygomycetes): their role in macro and microevolutionary processes. Mycotaxon 37:493-515.

Moyersoen B., Fitter A.H. and Alexander I.J. 1998. Spatial distribution of ectomycorrhizas and arbuscular mycorrhizas in Korup National Park rain forest, Cameroon, in relation to edaphic parameters. New Phytologist 139:311-320.

Nadian H., Smith S.E., Alston A.M. and Murray R.S. 1997. Effects of soil compaction on plant growth, phosphorus uptake and morphological characteristics of vesicular-arbuscular mycorrhizal colonization of Trifolium subterraneum. New Phytologist
135:303-311.

Nadian H., Smith S.E., Alston A.M., Murray R.S. and Siebert B.D. 1998. Effects of soil compaction on phosphorus uptake and growth of Trifolium subterraneum colonized by four species of vesicular-arbuscular mycorrhizal fungi. New Phytologist 139:155-165.

Newman E.I. and Reddell P. 1987. The distribution of mycorrhizas among families of vascular plants. New Phytologist 106:745751.

Newsham K.K., Fitter A.H. and Watkinson A.R. 1995a. Multi-functionality and biodiversity in arbuscular mycorrhizas. Trends in Ecology and Evolution 10:407-411.

Newsham K.K., Watkinson A.R. and Fitter A.H. 1995b. Rhizosphere and root infecting fungi and the design of ecological field experiments. Oecologia 102:230-237.

Nicolson T.H. 1960. Mycorrhizae in the Gramineae. II. Development in different habitats particularly sand dunes. Transactions of the British Mycological Society 43:132-145.

Owusu-Bennoah E. and Wild A. 1979. Autoradiography of the depletion zone of phosphate around onion roots in the presence of vesicular-arbuscular mycorrhiza. New Phytologist 82:133-140.

Pendleton R.L. and Smith B.N. 1983. Vesicular-arbuscular mycorrhizae of weedy and colonizer plant species at disturbed sites in Utah. Oecologia 59:296-301.

Pirozynski K.A. 1981. Interactions between fungi and plants through the ages. Canadian Journal of Botany 59:1824-1827.

Porter W.M., Robson A.D. and Abott L.K. 1987a. Field survey of the distribution of vesicular-arbuscular mycorrhizal fungi in relation to soil pH. Journal of Applied Ecology 24:659-662.

Porter W.M., Robson A.D. and Abott L.K. 1987b. Factors controlling the distribution of vesicular-arbuscular mycorrhizal fungi in relation to soil pH. Journal of Applied Ecology 4:663-672.

Powell C.L. 1979. Spread of mycorrhizal fungi through soil. New Zealand Journal of Agricultural Research 22:335-339.

Powell C.L. 1980. Mycorrhizal infectivity of eroded soils. Soil Biology and Biochemistry 12:247-250.

Read D.J., Koucheki H.K. and Hodgson J. 1976. Vesiculararbuscular mycorrhiza in natural vegetation systems. New Phytologist 76:641-653.

Sanders I.R. and Fitter A.H. 1992. The ecology and functioning of vesicular-arbuscular mycorrhizas in co-existing grassland species. I. Seasonal patterns of mycorrhizal occurrence and morphology. New Phytologist 120:517-524.

Sanders I.R., Clapp J. and Wiemken A. 1996. The genetic diversity of arbuscular mycorrhizal fungi in natural ecosystems -a key to understanding the ecology and functioning of the mycorrhizal symbiosis. New Phytologist 133:123-134.

St. John T.V. and Coleman D.C. 1982. The role of mycorrhizae in plant ecology. Canadian Journal of Botany 61:1005-1014.

Stahl P.D., Williams S.E. and Christensen M. 1988. Efficacy of native vesicular-arbuscular mycorrhizal fungi after severe soil disturbance. New Phytologist 110:347-354.

Stahl P.D., Christensen M. and Williams S.E. 1990. Population variation in the mycorrhizal fungus Glomus mosseae: uniform garden experiments. Mycological Research 94:1070-1076.

Streitwolf-Engel R., Boller T., Wiemken A. and Sanders I.R. 1997. Clonal growth traits of two Prunella species are determined by co-occurring arbuscular mycorrhizal fungi from a calcareous grassland. Journal of Ecology 85:181-191.

Sylvia D.M. 1986. Spatial and temporal distribution of vesicular- 
arbuscular mycorrhizal fungi associated with Uniola paniculata in Florida foredunes. Mycologia 78:728-734.

Sylvia D.M., Wilson D.O., Graham J.H., Madox J.J., Millner P., Morton J.B., Skipper H.D., Wright S.F. and Jarstfer A.G. 1993. Evaluation of vesicular-arbuscular mycorrhizal fungi in diverse plants and soils. Soil Biology and Biochemistry 25:705-713.

Søndergaard M. and Laegaard S. 1977. Vesicular-arbuscular mycorrhiza in some aquatic vascular plants. Nature 268:232-233.

Titus J.H. and del Moral R. 1998a. Vesicular-arbuscular mycorrhizae influence Mount St. Helens pioneers species in greenhouse experiments. Oikos 81:495-510.

Titus J.H. and del Moral R. 1998b. The role of mycorrhizal fungi and microsites in primary succession on Mount St. Helens. American Journal of Botany 85:370-375.

Trappe J.M. and Maser Ch. 1976. Germination of spores of Glomus macrocarpus (Endogonaceae) after passage through a rodent digestive tract. Mycologia 68:433-436.

Trappe J.M. 1988. Lessons from alpine fungi. Mycologia 80:1-10.

Turner S. and Friese C.F. 1998. Plant-mycorrhizal community dynamics associated with a moisture gradient with a rehabilitated prairie fen. Restoration Ecology 6:44-51.

Van der Heijden M.G.A, Boller T., Wiemken A. and Sanders I.R. 1998. Different arbuscular mycorrhizal fungal species are potential determinants of plant community structure. Ecology 79:2082-2091.

Virginia R.A., Jenkins M.B. and Jarrel W.M. 1986. Depth of root symbiont occurrence in soil. Biology and Fertility of Soils 2:127130.

Warcup J.H. 1981. The mycorrhizal relationships of Australian orchids. New Phytologist 87:371-381.

Warner A. and Mosse B. 1980. Independent spread of vesiculararbuscular mycorrhizal fungi in soil. Transactions of the British Mycological Society 74:407-410.

Warner N.J., Allen M.F. and MacMahon J.A. 1987. Dispersal agents of vesicular-arbuscular mycorrhizal fungi in a disturbed arid ecosystem. Mycologia 79:721-730.

West H.M., Fitter A.H. and Watkinson A.R. 1993a. The influence of three biocides on the fungal associates of the roots of Vulpia ciliata ssp. ambigua under natural conditions. Journal of Ecology 81:345-350.

West H.M., Fitter A.H. and Watkinson A.R. 1993b. Response of Vulpia ciliata ssp. ambigua to removal of mycorrhizal infection and to phosphate application under natural conditions. Journal of Ecology 81:351-358.

Whittingham J. and Read D.J. 1982. Vesicular-arbuscular mycorrhiza in natural vegetation systems. III. Nutrient transfer between plants with mycorrhizal interconnections. New Phytologist 90:277-284.

Wildman H.G. 1995. Influence of habitat on the physiological and metabolical diversity of fungi. Canadian Journal of Botany 73:S907-S916.

Wilson J.M. 1984. Competition for infection between vesiculararbuscular mycorrhizal fungi. New Phytologist 97:427-435.

Wilson G.W.T. and Hartnett D.C. 1997. Effects of mycorrhizae on plant growth and dynamics in experimental tallgrass prairie microcosm. American Journal of Botany 84:478-482.

Wilson G.W.T. and Hartnett D.C. 1998. Interspecific variation in plant responses to mycorrhizal colonization in tallgrass prairie. American Journal of Botany 85:1732-1738.

Zajicek J.M. and Hetrick B.A.D. 1986. The influence of soil depth on mycorrhizal colonization of forbs in the tallgrass prairie. Mycologia 78:316-320.

Zak J.C. and Visser S. 1996. An appraisal of soil fungal biodiversity: the crossroads between taxonomic and functional biodiversity. Biodiversity and Conservation 5:169-183.

Zoberi M.H. and Grace J.K. 1990. Fungi associated with the subterranean termite Reticulitermes flavipes in Ontario. Mycologia 82:289-294. 